$=$ 原 $\quad$ 著 $=$

$$
\begin{aligned}
& \text { バイダスを用いたサルモネラ迅速検出法の検討 } \\
& \text { 中川 } \text { 弘 }^{* 1, \dagger} \text { ・福 村 圭 } \text { 介 }^{* 1} \text { - 中村菜美子*2 ・澤 口 勧 }{ }^{* 3} \\
& \text { 内田和之草 ・伊藤 武*4 } \\
& (* 1 \text { 財団法人 沖縄県環境科学センター, *2 麻布大学, } \\
& \text { *3 日本ビオメリュ一株式会社, *4 財団法人 東京顕微鏡院) } \\
& \text { （受付 平成 } 18 \text { 年 } 3 \text { 月 } 13 \text { 日） } \\
& \text { （受理 平成 } 18 \text { 年 } 6 \text { 月 } 1 \text { 日） }
\end{aligned}
$$

\title{
Study of Simple and Rapid Detection of Salmonella spp. Using VIDAS
}

\author{
Hiroshi NaKagawa ${ }^{* 1,}{ }^{\dagger}$, Keisuke Fukumura ${ }^{* 1}$, Namiko NaKamura ${ }^{* 2}$, \\ Susumu SAwaguchI ${ }^{* 3}$, Kazuyuki UchidA ${ }^{* 3}$ and Takeshi ITo*4 \\ (*l Okinawa Environmental Research \& Technology Center, \\ 720 Kyoduka, Urazoe, Okinawa $901-2111{ }^{\dagger}$ Corresponding author) \\ (*2 Azabu University, 1-17-71 Fuchinobe, Sagamihara, Kanagawa 229-8501) \\ (*3 bioMerieux Japan Ltd., 2-12-28 Kita-Aoyama, Minato-ku, Tokyo 107-0061) \\ (*4 Tokyo Kenbikyoin Foundation, 44-1 Hakozaki-cho, Nihonbashi, \\ Chuou-ku, Tokyo 103-0015)
}

Both the incidence and number of patients with food-borne diseases caused by Salmonella still rank very high among total food-borne diseases, although both have been decreasing in recent years. The need for a simple and rapid alternative method of Salmonella testing is very high in the food industry because the conventional culture method includes two enrichment procedures and takes more than five days to isolate and identify a typical colony of Salmonella from food samples. VIDAS is an enzyme-linked fluorescent assay (ELFA) system that consists of a fully automated device and its reagents. In this study, we compared two protocols of the VIDAS method with the conventional culture method for detecting Salmonella using 40 food samples. Performances of protocols "VIDAS ICS + plate" and "VIDAS SLM AFNOR validated method" both showed higher sensitivity than the conventional culture method. These protocols were also excellent in terms of reduced time-toresults in addition to showing higher sensitivity. We also compared SMID 2, a new chromogenic agar plate for selective isolation of Salmonella, with DHL agar, a traditional agar plate for Salmonella testing. On SMID 2, typical colonies of Salmonella were much easier to identify (mainly by its characteristic color), and the frequency of appearance of typical colonies by bacteria other than Salmonella was much lower, although the Salmonella recovery rate did not differ between the two media.

Key words: Salmonella; VIDAS; Enzyme-linked fluorescent assay; Chromogenic agar

*1 焉901-2111 沖縄県浦添市経塚 720 番地

*2 荿229-8501 神奈川県相模原市㴊野辺 1-17-71
} 


\section{I. 緒 言}

近年, サルモネラ食中毒は減少傾向にあるが依然とし て件数，患者数ともに上位を占めている，サルモネラ食 中毒の主要な原因食品としては鷂卵之その加工品, その 他食肉類とその加工品などが挙げられる．食品中に存在 するサルモネラは共存する他の菌と比較して菌量が少な く，また加熱，冷凍あるいは乾燥などによって損傷を受 けている場合があるため，本菌を検出する際には従来か ら前増菌之選択增菌の 2 段階の培養が行われている。 そ のため食品からのサルモネラの分離，同定には 5 日間以 上を要することから，迅速で簡易なサルモネラ検出法の 確立が望まれている。近年，分離培養では酵素基質培地 が, 確認試験では ELISA などの免度学的手法, DNA プ ローブなどや PCR 法などの病因遺伝子検索，さらに生 化学的性状試験を応用したものなどさまざまな迅速検査 法が開発，実用化されている1,2).

自動免疫蛍光測定装置（ミニバイダス）およびその専 用試薬を用いたサルモネラの検出は, 海外で高く評価さ れており，その報告屯多( ${ }^{3 \sim 5)}$.

本研究は食品中のサルモネラの検出について，自動免 疫蛍光測定装置（ミニバイダス）およびその専用試薬を 用いたプロトコールを，日本に扔ける公定法と比較し， その有用性について検討した。 また，新たに開発された サルモネラの分離培地である SMID2 寒天平板培地の評 価も併せて行った。

\section{II. 材料および方法}

\section{1. サルモネラ検出用自動測定装置および専用試薬}

ELFA (Enzyme Linked Fluorescent Assay) を原理 とするミニバイダス（日本ビオメリュー）を用いた。ま た，専用サルモネラ用試薬として，バイダスアッセイ キットサルモネラ (VIDAS assay kit Salmonella，以下 VIDAS SLM) およびバイダス ICS サルモネラ濃縮用 キット (VIDAS Immuno-Concentration Salmonella, 以下 VIDAS ICS) を用いた。

\section{2. 測定原理}

バイダス（ミニバイダス）は，ELFA を原理とする自 動免疫蛍光測定装置である。

専用試薬はスパーとストリップから構成されている. スパーの内壁には抗体が固相されており，検体中の特異 抗原を捕捉する。この抗原にストリップ中のアルカリ フォスファターゼ標識抗体が結合し，さらにアルカリ フォスファターゼがストリップ中の 4-メチルウンベリ フェリルリン酸を加水分解する。続いて蛍光強度が測定 され，判定まで自動で行われる。なお上述した VIDAS ICS は，本原理によりサルモネラを特異的に集菌するた めの試薬である.

ミニバイダスの検出項目（食中毒関連）には E. coli O1576),7), サルモネラ ${ }^{3 \sim 5)}$, キャンピロバクター8), 黄色
ブドウ球菌由来エンテロトキシン9), リステリア10), リス テリアモノサイトゲネス ${ }^{11,12)}$ があり，目的によって専 用試薬を使い分ける。測定時間は検出項目によって異な り，約 40〜70 分である.

\section{3. 供試菌株}

Salmonella Enteritidis IFO3313 (以下 SE)

Salmonella Typhimurium ATCC14028（以下 ST)

\section{4. 供試材料}

卵類 (鵎卵, 温泉卵), 卵加工品 (プリン，カスタード 菓子, ポテトサラダ）, 冷凍食品（餃子，グラタン，ピラ ᄀ, 鶏から揚げ）, 肉類（豚肉, 生姜焼き用豚肉, 馬肉, ハンバーグパティ), 肉加工品 (ソーセージ, ロースト ビーフ, 生八ム), 野菜類 (カット野菜 3 件), 鶏肉類 (屯 あ 3 件, 手羽先, 骨付き肉, 軟骨, チキンパティ, 鵎ミ ンチ, 正肉ミンチ, ささみミンチ, 皮 2 件, 砂肝 2 件, むつ，きんかん，ハート，レバー 3 件）きのこ類（まい たけ）の合計 40 検体を用いた。

\section{5. 供試材料の細菌数確認}

供試材料の污染度合を確認するため，一般生菌数揖よ び大腸菌群数を以下の方法で測定した．供試材料 $25 \mathrm{~g}$ を滅菌ストマッカー袋に採取し，これに滅菌済み生理食 塩水 $225 \mathrm{~m} l$ を加えて $230 \mathrm{rpm}$ で 30 秒間ストマッキン グし，必要に応じて 10 倍ずつ段階希釈した後シャーレ 2 枚に $1 \mathrm{ml}$ ずつ分注した。一般生菌数は標準寒天培地 （栄研化学）で混釈して $35^{\circ} \mathrm{C}$ で 48 時間, 大腸菌群数は デソキシコレート寒天培地 (栄研化学) で混釈して $35^{\circ} \mathrm{C}$ で 20 時間培養した後常法に従って菌数を算出した.

\section{6. サルモネラ接種試験法}

\section{1 接種菌液の調製と菌数確認}

接種菌液は前述 2 菌株を $10 \sim 30 \mathrm{cfu} / 100 \mu \mathrm{l}$ になる よう調製し各供試材料に接種した。接種菌液の菌数の確 認は, 菌液をトリプトソイ寒天培地（日本ビオメリュー： 以下 TSA）平板 10 枚にそれぞれ $100 \mu l$ ずつ滴下しコ ンラージ棒で表面塗抹後, $35^{\circ} \mathrm{C}$ で 24 時間培養後に出現 した集落を数え算出した。

\section{2 供試材料の調製と菌液の接種}

供試材料の可食部 $25 \mathrm{~g}$ を, 検体 1 種類につき 3 件, それぞれ滅菌ストマッカー袋に無菌的に採取した。うち 2 件にはSE またはST の菌液をそれぞれ $100 \mu l$ 接種 し，1 件はサルモネラ未接種で試験に供した。

\section{7. サルモネラの検出法}

\section{1 検体の希积およひ前増菌}

検体 $25 \mathrm{~g}$ に $225 \mathrm{~m} l$ の滅菌ペプトン緩衝液（栄研化 学：以下 BPW）を加え，230 rpm で 30 秒間ストマッキ ングした．その後, 公定法における卵と卵加工品（後述 7.4.1）は $35^{\circ} \mathrm{C}$ で $20 \sim 24$ 時間，それ以外は $35^{\circ} \mathrm{C}$ で $16 \sim$ 20 時間培養した。

7.2 バイダス ICS+ plate 法 (Fig. 1)

前增菌液 $0.8 \mathrm{~m} l$ をバイダス ICS で濃縮し, 濃縮液を DHL 寒天培地 (栄研化学: 以下 DHL) および SMID2 寒 


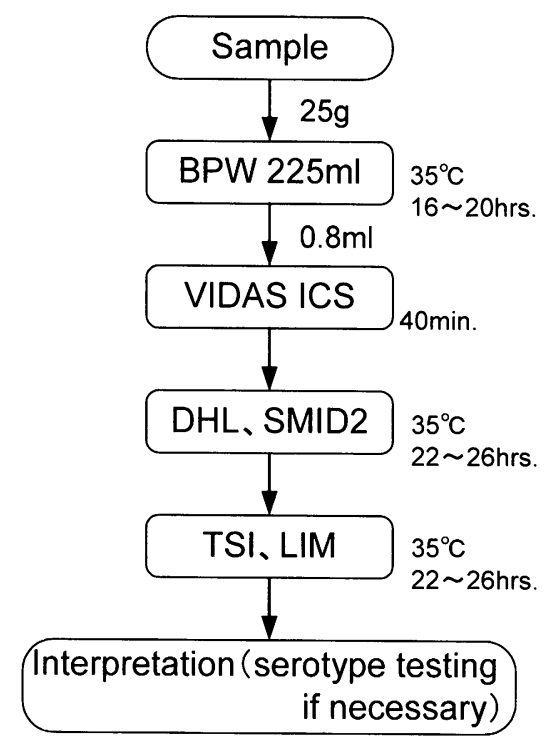

Fig. 1. VIDAS ICS + plate method.

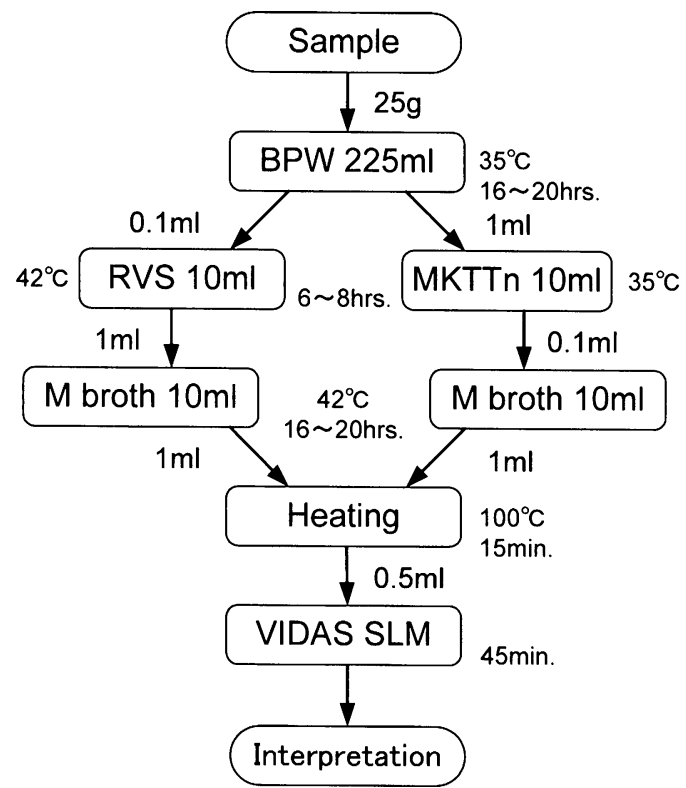

Fig. 2. VIDAS SLM; AFNOR validated method.

天培地（日本ビオメリュー：以下 SMID2）に塗抹し, $35^{\circ} \mathrm{C}$ で $22 \sim 26$ 時間培養した. サルモネラ未接種試験で 出現したサルモネラと疑われる集落は TSI 培地 (栄研化 学：以下 TSI）および LIM 培地（栄研化学：以下 LIM) に接種し, $35^{\circ} \mathrm{C}$ で 22〜26 時間培養した.この確認試験 でサルモネラの生化学性状を示した場合は $\mathrm{O}$ 多価血清 （デンカ生研）で凝集したものをサルモネラ陽性とした。 サルモネラを接種した供試材料について分離培地上に出 現したサルモネラが疑われる集落は，SEを接種したも のについては O 多価血清で，ST を接種したものについ ては O4 血清（デンカ生研）で凝集したものをサルモネ ラ陽性とした。

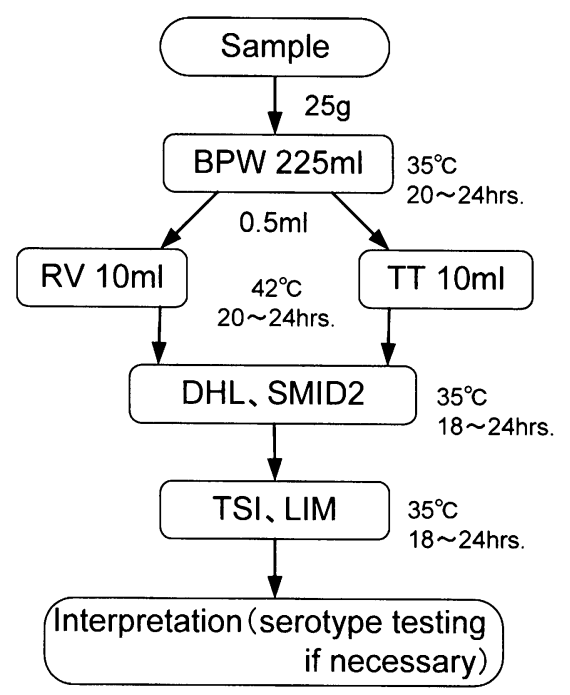

Fig. 3. Conventional culture method (for eggs).

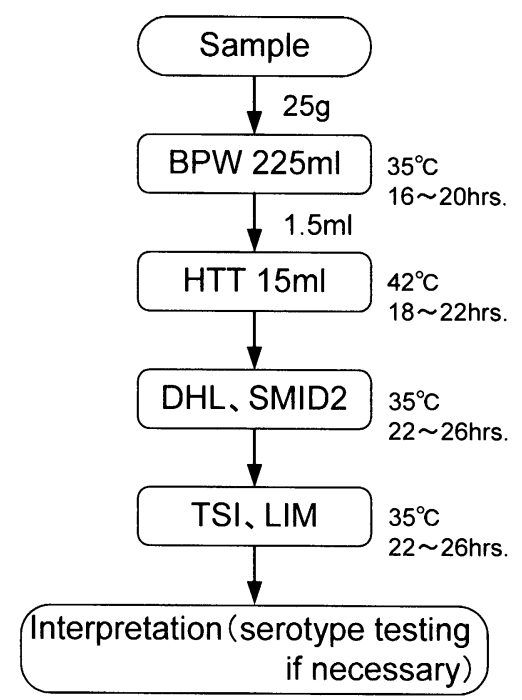

Fig. 4. Conventional culture method (for samples other than eggs).

\section{3 バィダス SLM. AFNOR（仏名：Association}

Francaise de Normalisation) 承認法 (Fig. 2)

前増菌液 $0.1 \mathrm{~m} l$ を $10 \mathrm{~m} l$ のラパポートバシリアディ スソイブイヨン（日本ビオメリュー：以下 RVS）へ，別 途 $1 \mathrm{~m} l$ を $10 \mathrm{~m} l$ のミューラーコフマンテトラチオネー トブイヨン（日本ビオメリュー：以下 MKTTn）へそれ ぞれ接種した。前者は $42^{\circ} \mathrm{C}$, 後者は $35^{\circ} \mathrm{C}$ でそれぞれ 6 $\sim 8$ 時間培養した培養液を前者は $1 \mathrm{~m} l$, 後者は $0.1 \mathrm{~m} l$ それぞれ $10 \mathrm{ml}$ の M ブイヨン（日本ビオメリュー）に 接種し, $42^{\circ} \mathrm{C}$ で 16〜20 時間培養した. 培養後, 各々の 培養液から $1 \mathrm{~m} l$ ずつ採取し混ぜ合わせた $2 \mathrm{~m} l$ を $100^{\circ} \mathrm{C}$ で 15 分熱処理し，その $0.5 \mathrm{ml}$ をバイダス $\mathrm{SLM}$ に分注し、ミニバイダスで測定した。

\section{4 公定法}

7.4.1 卵と卵加工品 (Fig. 3)

前増菌液 $0.5 \mathrm{ml}$ を $10 \mathrm{ml}$ のラパポートバシリアディ 
スブイヨン（日本ビオメリュー：以下 RV）とテトラチオ ネートブイヨン（栄研化学：以下 TT）にそれぞれ接種 し, $42^{\circ} \mathrm{C}$ で 20〜24 時間培養した.これら培養液 1 白金 耳をDHL および SMID2 にそれぞれ画線塗抹し， $35^{\circ} \mathrm{C}$
で18〜24 時間培養した。サルモネラ未接種試験で出現 した集落のうちサルモネラが疑われる集落はTSI およ び LIM に接種し， $35^{\circ} \mathrm{C}$ で $18 \sim 24$ 時間培養した。これ らの確認培地でサルモネラの生化学性状を示した場合,

Table 1. Detection of Salmonella from food samples tested

\begin{tabular}{|c|c|c|c|c|c|c|}
\hline \multirow{3}{*}{ Category of food } & \multirow{3}{*}{ The name of foods } & \multicolumn{3}{|c|}{ Results } & \multicolumn{2}{|c|}{$\begin{array}{l}\text { Microbiological flora of } \\
\text { samples (cfu/g) }\end{array}$} \\
\hline & & \multirow{2}{*}{$\begin{array}{c}\text { Conventional } \\
\text { culture method }\end{array}$} & \multicolumn{2}{|c|}{ VIDAS } & \multirow{2}{*}{$\begin{array}{l}\text { Total viable } \\
\text { count }\end{array}$} & \multirow{2}{*}{$\begin{array}{l}\text { Total } \\
\text { coliforms }\end{array}$} \\
\hline & & & ICS + plate & SLM (AFNOR) & & \\
\hline \multirow[t]{2}{*}{ Egg } & Onsen tamago & - & - & - & $<300$ & $<10$ \\
\hline & Raw egg & + & - & - & $<300$ & $<10$ \\
\hline \multirow{3}{*}{$\begin{array}{l}\text { Egg-processed } \\
\text { food }\end{array}$} & Pudding & - & - & - & $<300$ & $<10$ \\
\hline & Custard cake & - & - & - & $7.9 \times 10^{2}$ & $<10$ \\
\hline & Potato salad & - & - & - & $3.2 \times 10^{4}$ & $6.5 \times 10$ \\
\hline \multirow[t]{4}{*}{ Frozen food } & Gyoza & - & - & - & $<300$ & $<10$ \\
\hline & Gratin & - & - & - & $<300$ & $<10$ \\
\hline & Pilaf & - & - & - & $<300$ & $<10$ \\
\hline & Fried chicken & - & - & - & $<300$ & $<10$ \\
\hline \multirow[t]{4}{*}{ Meat } & Pork & - & - & - & $1.2 \times 10^{4}$ & $<10$ \\
\hline & Pork seasoned with ginger & - & - & - & $1.2 \times 10^{5}$ & $1.4 \times 10^{3}$ \\
\hline & Horse meat & - & - & - & $9.7 \times 10^{2}$ & $<10$ \\
\hline & Hamburger patty & - & - & - & $1.4 \times 10^{4}$ & $9.5 \times 10$ \\
\hline \multirow{3}{*}{$\begin{array}{l}\text { Processed meat } \\
\text { product }\end{array}$} & Sausage & - & - & - & $<300$ & $<10$ \\
\hline & Roast beef & - & - & - & $1.2 \times 10^{3}$ & $<10$ \\
\hline & Uncured ham & - & - & - & $<300$ & $<10$ \\
\hline \multirow[t]{3}{*}{ Vegetables } & Cut vegetables 1 & - & - & - & $5.1 \times 10^{5}$ & $1.9 \times 10^{4}$ \\
\hline & Cut vegetables 2 & - & - & - & $<300$ & $<10$ \\
\hline & Cut vegetables 3 & - & - & - & $4.6 \times 10^{6}$ & $4.1 \times 10^{5}$ \\
\hline \multirow[t]{20}{*}{ Chicken meat } & Thigh 1 & - & + & + & $2.2 \times 10^{4}$ & $3.0 \times 10$ \\
\hline & Thigh 2 & - & - & - & $5.4 \times 10^{3}$ & $8.3 \times 10^{2}$ \\
\hline & Thigh 3 & - & - & - & $1.1 \times 10^{4}$ & $1.7 \times 10^{2}$ \\
\hline & Wing & + & - & + & $2.7 \times 10^{6}$ & $1.3 \times 10^{4}$ \\
\hline & Drumstick & - & - & - & $5.1 \times 10^{3}$ & $2.4 \times 10^{2}$ \\
\hline & Cartilage & - & - & - & $2.4 \times 10^{4}$ & $5.1 \times 10^{2}$ \\
\hline & Chicken putty & + & + & + & $9.9 \times 10^{3}$ & $2.5 \times 10^{2}$ \\
\hline & Ground meat 1 & + & - & + & $4.5 \times 10^{4}$ & $5.3 \times 10^{2}$ \\
\hline & Ground meat 2 & - & - & - & $9.5 \times 10^{4}$ & $5.1 \times 10^{3}$ \\
\hline & Ground breast tender & - & - & + & $1.2 \times 10^{5}$ & $2.8 \times 10^{3}$ \\
\hline & Skin 1 & - & - & - & $4.4 \times 10^{4}$ & $7.5 \times 10^{1}$ \\
\hline & Skin 2 & + & - & + & $1.5 \times 10^{6}$ & $9.5 \times 10^{1}$ \\
\hline & Gizzard 1 & - & - & - & $1.5 \times 10^{5}$ & $6.6 \times 10^{2}$ \\
\hline & Gizzard 2 & - & - & - & $3.6 \times 10^{3}$ & $2.5 \times 10^{2}$ \\
\hline & Giblets & + & - & + & $2.1 \times 10^{5}$ & $1.6 \times 10^{4}$ \\
\hline & Ovary & - & - & - & $4.0 \times 10^{4}$ & $4.1 \times 10^{3}$ \\
\hline & Heart & - & - & - & $2.7 \times 10^{4}$ & $2.1 \times 10^{2}$ \\
\hline & Liver 1 & - & - & - & $7.8 \times 10^{4}$ & $4.9 \times 10^{3}$ \\
\hline & Liver 2 & - & - & + & $5.6 \times 10^{3}$ & $1.8 \times 10^{2}$ \\
\hline & Liver 3 & + & + & + & $1.4 \times 10^{4}$ & $7.5 \times 10^{2}$ \\
\hline Mushroom & Maitake mushroom & - & - & + & $1.1 \times 10^{4}$ & $5.1 \times 10^{3}$ \\
\hline \multicolumn{2}{|l|}{ Number of tests } & 40 & 40 & 40 & & \\
\hline \multicolumn{2}{|c|}{ Number of positive samples } & 7 & 3 & 10 & & \\
\hline \multicolumn{2}{|c|}{$\begin{array}{l}\text { Accordance with conventional culture } \\
\text { method (number of samples) }\end{array}$} & - & 34 & 35 & & \\
\hline \multicolumn{2}{|c|}{$\begin{array}{l}\text { Accordance rate with conventional culture } \\
\text { method }\end{array}$} & - & $85.00 \%$ & $87.50 \%$ & & \\
\hline
\end{tabular}


およびサルモネラを接種した供試材料について分離培地 上に出現したサルモネラが疑われる集落については血清 学的試験でサルモネラの有無を判定した。

\subsection{2 卵以外の食品 (Fig. 4)}

前増菌液 $1.5 \mathrm{ml}$ を $15 \mathrm{ml}$ のハーナテトラチオネート ブイヨン (栄研化学: 以下 HTT) に接種し $42^{\circ} \mathrm{C}$ で 18 22 時間培養した後, その 1 白金耳を DHL および SMID 2 に画線塗抹し， $35^{\circ} \mathrm{C}$ で 22〜26 時間培養した. サルモ ネラ未接種試験で出現した集落のうちサルモネラが疑わ れる集落を TSI および LIM に接種し， $35^{\circ} \mathrm{C}$ で $22 \sim 26$ 時間培養した。これらの確認培地でサルモネラの生化学 性状を示した場合，およびサルモネラを接種した供試材 料から出現したサルモネラと疑われる集落については前 述の血清学的試験でサルモネラの有無を判定した。

\section{III. 結 果}

\section{1. 供試材料からのサルモネラの検出}

合計 40 検体中，サルモネラが検出されたものは公定 法で 7 件, バイダス ICS + plate 法で 3 件, バイダス SLM；AFNOR 承認法で 10 件であった (Table 1).

\section{2. 食品にサルモネラを添加した場合の各法によるサ} ルモネラの検出

各検体に SE $(8.2 \sim 16.9 \mathrm{cfu} / 100 \mu l)$, ST $(10.3 \sim 14.3$ $\mathrm{cfu} / 100 \mu l)$ を接種し，公定法，バイダス ICS+plate 法 およびバイダス SLM; AFNOR 承認法の 3 法でサルモ ネラの検出状況を比較した結果をそれぞれ Table 2 およ び Table 3 に示した.

$\mathrm{SE}$ を接種した場合にサルモネラが検出されたのは, 公定法では 36 件 (90.0\%) であったが，バイダス ICS+ plate 法およびバイダス SLM; AFNOR 承認法では 39 件 (97.5\%) であった. STを接種した場合は，公定法で は 39 件 (97.5\%)，バイダス ICS + plate 法では 38 件 (95.0\%)，バイダス SLM; AFNOR 承認法では 40 件 (100\%) からサルモネラが検出され，いずれの菌を接種 した場合においてもバイダス SLM; AFNOR 承認法が 最も検出率が高い結果であった。 サルモネラを接種した 合計 80 試験におけるサルモネラの検出は，公定法では 75 件 (93.8\%)，バイダス ICS + plate 法では 77 件 (96.3\%)，バィダス SLM; AFNOR 承認法では 79 件 (98.8\%) で，バイダスを用いた両プロトコールは公定法 よりも検出率が高い結果が得られた.

\section{3. 公定法との一致率}

サルモネラ接種および未接種の合計 120 試験におけ る公定法との一致率は, バイダス ICS + plate 法では 91.7\%，バイダス SLM; AFNOR 承認法では 92.5\%で あった。また，サルモネラを接種した合計 80 試験にお ける公定法との一致率は, バイダス ICS + plate 法, バイ ダス SLM; AFNOR 承認法ともに 95.0\%であった。

\section{4. 分離培地の検討}

サルモネラ未接種の試験品 40 検体およびサルモネラ
を接種した試験品 80 検体について，公定法およびバイ ダス ICS + plate 法での合計 240 試験検体のうち DHL では 150 検体, SMID2 で分離した場合は 155 検体から サルモネラが分離され，両培地間で検出率には著しい差 は認められなかった，分離培地の鑑別能を比較するた め, 分離培地上でサルモネラが疑われた検体と培地別の 結果を Table 4 に示した. サルモネラ未接種の 40 検体 において培地上でサルモネラが疑われたが確認試験で陰 性と判定された検体（偽陽性）について分離培地別にみ ると, DHL は公定法では 15 検体, バイダス ICS + plate 法では 20 検体認められたのに対し, SMID2 は公定法で は 3 検体, バイダス ICS + plate 法では 19 検体と, SMID2 は偽陽性数が少ない結果であった。またこれら サルモネラが疑われる集落を形成した検体は一般細菌数 の菌数が高いものや大腸菌群が検出されるなど細菌の污 染度が高い傾向であった。

\section{IV. 考察}

食材 40 検体を用い, 公定法, バイダス ICS + plate 法, バイダス SLM; AFNOR 承認法の 3 法を比較検討し た。その結果，バイダス SLM; AFNOR 承認法が公定法 およびバイダス ICS + plate 法よりあ高い検出率を示 し，他の 2 法より優れた方法であることが示唆された. バイダス SLM; AFNOR 承認法は，選択増菌に ISO (International Organization for Standardization) のサル モネラ検査 (ISO 6579) ${ }^{13)}$ に指定されている RVS と MKTTnの 2 種類の液体培地を用いており，公定法の HTTだけでは増菌され難かったサルモネラが増菌され たと考えられるとともに，M ブイヨンでの増菌過程を加 えることにより鞭毛の発育が促進され，少量のサルモネ ラであ検出が可能となったと考えられる．M ブイヨンは 培地成分のマンノースとクエン酸ナトリウムが栄養素と なりサルモネラの発育を促進し, マンノースが鞭毛の非 特異的な凝集を抑制し鞭毛の発育を促進することが知ら れている14).

バイダス ICS + plate 法む，サルモネラを接種した場 合の検出率は公定法よりも高い結果であった．このプロ トコールでは ICS で集菌することで集落形成に十分な 量のサルモネラが集菌できるとともにサルモネラ以外の 菌を効率よく排除することができ，これが良好な結果に つながったものと考えられる。

しかしながら，今回試験に供した食材は大腸菌群によ る污染度が高いものも多く，ICS で集菌したにもかかわ らず分離培地でサルモネラを分離するのが困難なものも 認められた. サルモネラ未接種時に 3 法いずれでもサル モネラが検出された検体の大腸菌群数は $10^{1} \sim 10^{2} オ ー$ ダーであったのに対し，バイダス ICS + plate 法のみで サルモネラが検出できなかった検体の大腸菌群数は $10^{1}$ 〜 $10^{4}$ オーダーであった。 検体に大腸菌群などのきょう 雑菌が多い場合, バイダス ICS での集菌の際に類属反応 
Table 2. Comparison of each method for detection of Salmonella from food samples spiked with SE*

\begin{tabular}{|c|c|c|c|c|c|}
\hline \multirow{3}{*}{ Category of food } & \multirow{3}{*}{ The name of foods } & \multicolumn{3}{|c|}{ Results } & \multirow{3}{*}{$\begin{array}{l}\text { Number of } \\
\text { cells innoculated }\end{array}$} \\
\hline & & \multirow{2}{*}{$\begin{array}{c}\text { Conventional } \\
\text { culture method }\end{array}$} & \multicolumn{2}{|c|}{ VIDAS } & \\
\hline & & & ICS + plate & SLM (AFNOR) & \\
\hline \multirow[t]{2}{*}{ Egg } & Onsen tamago & + & + & + & 8.2 \\
\hline & Raw egg & + & + & + & 11.8 \\
\hline \multirow[t]{3}{*}{ Egg-processed food } & Pudding & + & + & + & 16.9 \\
\hline & Custard cake & + & + & + & 9.9 \\
\hline & Potato salad & - & + & + & 8.2 \\
\hline \multirow[t]{4}{*}{ Frozen food } & Gyoza & + & + & + & 9.9 \\
\hline & Gratin & + & + & + & 9.9 \\
\hline & Pilaf & + & + & + & 16.1 \\
\hline & Fried chicken & + & + & + & 16.1 \\
\hline \multirow[t]{4}{*}{ Meat } & Pork & + & + & + & 8.2 \\
\hline & Pork seasoned with ginger & + & + & + & 16.1 \\
\hline & Horse meat & + & + & + & 9.9 \\
\hline & Hamburger patty & + & + & + & 16.1 \\
\hline \multirow{3}{*}{$\begin{array}{l}\text { Processed meat } \\
\text { product }\end{array}$} & Sausage & + & + & + & 16.9 \\
\hline & Roast beef & + & + & + & 16.9 \\
\hline & Uncured ham & + & + & + & 11.8 \\
\hline \multirow[t]{3}{*}{ Vegetables } & Cut vegetables 1 & - & - & + & 8.2 \\
\hline & Cut vegetables 2 & + & + & + & 16.9 \\
\hline & Cut vegetables 3 & + & + & + & 11.8 \\
\hline \multirow[t]{20}{*}{ Chicken meat } & Thigh 1 & + & + & + & 11.8 \\
\hline & Thigh 2 & + & + & + & 14.3 \\
\hline & Thigh 3 & + & + & + & 11.2 \\
\hline & Wing & + & + & + & 11.2 \\
\hline & Drumstick & + & + & + & 14.3 \\
\hline & Cartilage & + & + & + & 14.3 \\
\hline & Chicken putty & + & + & + & 14.3 \\
\hline & Ground meat 1 & + & + & + & 11.2 \\
\hline & Ground meat 2 & + & + & + & 14.3 \\
\hline & Ground breast tender & + & + & + & 14.3 \\
\hline & Skin 1 & + & + & + & 11.2 \\
\hline & Skin 2 & + & + & + & 11.2 \\
\hline & Gizzard 1 & + & + & + & 14.3 \\
\hline & Gizzard 2 & + & + & + & 11.2 \\
\hline & Giblets & + & + & + & 14.3 \\
\hline & Ovary & + & + & + & 14.3 \\
\hline & Heart & + & + & + & 11.2 \\
\hline & Liver 1 & + & + & + & 14.3 \\
\hline & Liver 2 & + & + & + & 11.2 \\
\hline & Liver 3 & + & + & + & 11.2 \\
\hline Mushroom & Maitake mushroom & + & + & + & 11.2 \\
\hline \multicolumn{2}{|l|}{ Number of tests } & 40 & 40 & 40 & \\
\hline \multicolumn{2}{|c|}{ Number of positive samples } & 36 & 39 & 39 & \\
\hline \multicolumn{2}{|l|}{ Positive rate } & $90.00 \%$ & $97.50 \%$ & $97.50 \%$ & \\
\hline \multicolumn{2}{|c|}{$\begin{array}{l}\text { Accordance with conventional culture method } \\
\text { (number of samples) }\end{array}$} & - & 37 & 37 & \\
\hline \multicolumn{2}{|c|}{$\begin{array}{l}\text { Accordance rate with conventional culture } \\
\text { method }\end{array}$} & - & $85.00 \%$ & $87.50 \%$ & \\
\hline
\end{tabular}

* SE: Salmonella Enteritidis 
162 日食微誌 Vol. 23, No. 32006

Table 3. Comparison of each method for detection of Salmonella from food samples spiked with ST*

\begin{tabular}{|c|c|c|c|c|c|}
\hline \multirow{3}{*}{ Category of food } & \multirow{3}{*}{ The name of foods } & \multicolumn{3}{|c|}{ Results } & \multirow{3}{*}{$\begin{array}{l}\text { Number of } \\
\text { cells innoculated } \\
(\mathrm{cfu} / 25 \mathrm{~g})\end{array}$} \\
\hline & & \multirow{2}{*}{$\begin{array}{l}\text { Conventional } \\
\text { culture method }\end{array}$} & \multicolumn{2}{|c|}{ VIDAS } & \\
\hline & & & ICS + plate & SLM (AFNOR) & \\
\hline \multirow[t]{2}{*}{ Egg } & Onsen tamago & + & + & + & 12.6 \\
\hline & Raw egg & + & + & + & 13.6 \\
\hline \multirow[t]{3}{*}{ Egg-processed food } & Pudding & + & + & + & 11.8 \\
\hline & Custard cake & + & + & + & 10.3 \\
\hline & Potato salad & + & + & + & 12.6 \\
\hline \multirow[t]{4}{*}{ Frozen food } & Gyoza & + & + & + & 10.3 \\
\hline & Gratin & + & + & + & 10.3 \\
\hline & Pilaf & + & + & + & 10.6 \\
\hline & Fried chicken & + & + & + & 10.6 \\
\hline \multirow[t]{4}{*}{ Meat } & Pork & + & + & + & 12.6 \\
\hline & Pork seasoned with ginger & + & + & + & 10.6 \\
\hline & Horse meat & + & + & + & 10.3 \\
\hline & Hamburger patty & + & + & + & 10.6 \\
\hline \multirow{3}{*}{$\begin{array}{l}\text { Processed meat } \\
\text { product }\end{array}$} & Sausage & + & + & + & 11.8 \\
\hline & Roast beef & + & + & + & 11.8 \\
\hline & Uncured ham & + & + & + & 13.6 \\
\hline \multirow[t]{3}{*}{ Vegetables } & Cut vegetables 1 & - & - & + & 12.6 \\
\hline & Cut vegetables 2 & + & + & + & 11.8 \\
\hline & Cut vegetables 3 & + & + & + & 13.6 \\
\hline \multirow[t]{20}{*}{ Chicken meat } & Thigh 1 & + & + & + & 13.6 \\
\hline & Thigh 2 & + & + & + & 11.9 \\
\hline & Thigh 3 & + & + & + & 14.3 \\
\hline & Wing & + & + & + & 14.3 \\
\hline & Drumstick & + & + & + & 11.9 \\
\hline & Cartilage & + & + & + & 11.9 \\
\hline & Chicken putty & + & + & + & 11.9 \\
\hline & Ground meat 1 & + & + & + & 14.3 \\
\hline & Ground meat 2 & + & + & + & 11.9 \\
\hline & Ground breast tender & + & + & + & 11.9 \\
\hline & Skin 1 & + & + & + & 14.3 \\
\hline & Skin 2 & + & + & + & 14.3 \\
\hline & Gizzard 1 & + & + & + & 11.9 \\
\hline & Gizzard 2 & + & + & + & 14.3 \\
\hline & Giblets & + & + & + & 11.9 \\
\hline & Ovary & + & + & + & 11.9 \\
\hline & Heart & + & - & + & 14.3 \\
\hline & Liver 1 & + & + & + & 11.9 \\
\hline & Liver 2 & + & + & + & 14.3 \\
\hline & Liver 3 & + & + & + & 14.3 \\
\hline Mushroom & Maitake mushroom & + & + & + & 14.3 \\
\hline \multicolumn{2}{|l|}{ Number of tests } & 40 & 40 & 40 & \\
\hline \multicolumn{2}{|c|}{ Number of positive samples } & 39 & 38 & 40 & \\
\hline \multicolumn{2}{|l|}{ Positive rate } & $97.50 \%$ & $95.00 \%$ & $100.00 \%$ & \\
\hline \multicolumn{2}{|c|}{$\begin{array}{l}\text { Accordance with conventional culture method } \\
\text { (number of samples) }\end{array}$} & - & 39 & 39 & \\
\hline \multicolumn{2}{|c|}{$\begin{array}{l}\text { Accordance rate with conventional culture } \\
\text { method }\end{array}$} & - & $97.50 \%$ & $97.50 \%$ & \\
\hline
\end{tabular}

* SE: Salmonella Enteritidis 
Table 4. Samples detected typical colony of Salmonella on selective agar plate

\begin{tabular}{|c|c|c|c|c|c|}
\hline \multirow{3}{*}{ Category of food } & \multirow{3}{*}{ The name of foods } & \multicolumn{4}{|c|}{ Results } \\
\hline & & \multicolumn{2}{|c|}{$\begin{array}{l}\text { Conventional } \\
\text { culture method }\end{array}$} & \multicolumn{2}{|c|}{$\begin{array}{l}\text { VIDAS } \\
\text { ICS + plate }\end{array}$} \\
\hline & & DHL & SMID2 & DHL & SMID2 \\
\hline Egg-processed food & Potato salad & - & - & \pm & - \\
\hline Frozen food & Gratin & - & - & - & \pm \\
\hline Meat & $\begin{array}{l}\text { Pork seasoned with ginger } \\
\text { Horse meat } \\
\text { Hamburger patty }\end{array}$ & $\begin{array}{l}- \\
- \\
\pm\end{array}$ & $\begin{array}{l}- \\
- \\
-\end{array}$ & $\begin{array}{l} \pm \\
- \\
\pm\end{array}$ & $\begin{array}{l}- \\
- \\
\pm\end{array}$ \\
\hline Vegetables & $\begin{array}{l}\text { Cut vegetables } 1 \\
\text { Cut vegetables } 2 \\
\text { Cut vegetables } 3 \\
\end{array}$ & $\begin{array}{l}- \\
- \\
-\end{array}$ & $\begin{array}{l}- \\
- \\
-\end{array}$ & $\begin{array}{l} \pm \\
- \\
\pm\end{array}$ & $\begin{array}{l} \pm \\
\pm \\
\pm\end{array}$ \\
\hline Chicken meat & $\begin{array}{l}\text { Thigh } 1 \\
\text { Thigh } 2 \\
\text { Thigh } 3 \\
\text { Wing } \\
\text { Drumstick } \\
\text { Cartilage } \\
\text { Ground meat } 1 \\
\text { Ground meat } 2 \\
\text { Ground breast tender } \\
\text { Skin 1 } \\
\text { Skin } 2 \\
\text { Gizzard 1 } \\
\text { Gizzard } 2 \\
\text { Giblets } \\
\text { Heart } \\
\text { Liver } 1 \\
\text { Liver } 3\end{array}$ & $\begin{array}{l} \pm \\
\pm \\
\pm \\
\pm \\
- \\
\pm \\
\pm \\
\pm \\
\pm \\
\pm \\
+ \\
\pm \\
\pm \\
\pm \\
\pm \\
\pm \\
+\end{array}$ & $\begin{array}{l}- \\
- \\
\pm \\
+ \\
- \\
- \\
+ \\
- \\
\pm \\
- \\
+ \\
- \\
\pm \\
+ \\
- \\
- \\
+\end{array}$ & $\begin{array}{l} \pm \\
\pm \\
\pm \\
\pm \\
\pm \\
\pm \\
\pm \\
- \\
\pm \\
\pm \\
\pm \\
\pm \\
\pm \\
\pm \\
\pm \\
- \\
+\end{array}$ & $\begin{array}{l}+ \\
\pm \\
\pm \\
\pm \\
- \\
\pm \\
\pm \\
\pm \\
\pm \\
\pm \\
\pm \\
\pm \\
\pm \\
- \\
\pm \\
\pm \\
+\end{array}$ \\
\hline Mushroom & Maitake mushroom & - & - & - & \pm \\
\hline \multicolumn{2}{|l|}{ Number of tests } & \multicolumn{2}{|c|}{26} & \multicolumn{2}{|c|}{26} \\
\hline Number of false posi & e samples** & 15 & 3 & 20 & 19 \\
\hline
\end{tabular}

\pm Sample confirmed negative by confirmation testing, althogh detected typical colonies on selective agar plate.

などの影響を受けることで，分離平板培地の選択と塗抹 方法がサルモネラの検出に影響を与えることが推察され る.

食品では, 増菌培養後には多種類の菌が存在しており 全体に占める目的菌の数は少ないと報告されている ${ }^{15)}$. 本研究ではサルモネラ損傷菌の回復を目的として前増菌 に BPW を用いたが，これにより食品中に存在する大腸 菌群などのきょう雑菌の生育が優勢になりやすかったこ とも考えられる. 特に大腸菌群数の高かったカット野菜 1 および 3 などでは，サルモネラを接種しても検出でき ない例が見られた。 きょう雑菌の増殖抑制と損傷菌を含 めたサルモネラの回収どちらがより重要かを本結果から 明確にすることは困難であるが，いずれにせよサルモネ ラの検出率は選択増菌培地により大きく変動することか ら ${ }^{16)}$ ，サルモネラを検出可能な菌量にまで確実に増殖さ せ，さらにきょう雑菌の影響を抑えることができる増菌 法がサルモネラの検出率の向上につながるものと考えら れる.
今回分離培地として 2 種類の培地を用いた。 そのうち SMID2 は日本ビオメリューが新たに開発した培地で, 前身の SMID と比較すると Salmonella Arizonae など の鑑別が可能になるなどの改良がなされたものである. この SMID2 およびDHL の比較において, 検出率に大 きな差は認められなかった，しかし，サルモネラ集落の 鑑別の容易さは DHL と比較し SMID2 は定形集落の色 調が明瞭であり, かつ偽陽性の頻度も低く, 鑑別が容易 な点が優れた結果であった。この要因としては, DHLで のサルモネラの検出は硫化水素の産生による黒色集落を 指標にするが, 多くの菌が抑制されるとはいえ, Citrobacter freundii および Proteus spp. あまた黒色集 落を形成し，しばしばサルモネラと見誤られることが挙 げられる. 本研究であ, いくつかのサンプルで DHLに 発育した黒色集落がアピマニュアルキット（日本ビオメ リュー) で Proteus と同定された. 一方, SMID2 ではサ ルモネラに特異的なエステラーゼ活性により集落はピン ク〜赤紫色を呈するが, 本試験では青紫色の集落につい 
てあすべてを疑わしい集落と判定した。これらのうちサ ルモネラの血清による判定が陰性となった集落は Proteus, Serratia, Enterobacter, Aeromonas, Pseudomonas と同定された。 これらの菌を SMID2 に画線塗抹 し集落を形成させサルモネラの集落と比較したところ， Pseudomonasについてはサルモネラ集落との鑑別は困 難であったが，それ以外は色調などの鑑別が可能であっ た。したがって，判定に慣れることにより，SMID2に発 育した集落の判定が容易になると考えられる。 また最 近, サルモネラの代表的な生化学的性状である硫化水素 産生能を有さない株が食中毒の原因となることが危惧さ れていることから, 硫化水素非産生のサルモネラであっ てあサルモネラと判定できる SMID2 は有効であると考 えられる。

以上，バイダス SLM; AFNOR 承認法は比較したプロ トコール中最も検出感度が高く, 検出時間も公定法より 約 2 日短縮となった。 また，バイダス ICS + plate 法む 検出時間は公定法より約 1 日短縮でき, 検出感度も公定 法より高い結果が得られた。さらに分離培地として DHL に加え SMID2 を併用することで平板上のサルモ ネラ集落の鑑別む容易かつ確実となることから，これら は食品加ら少ルモネラの検出に有効な検查法と考えら れる.

\section{V. まとめ}

食品からのサルモネラの検出について, 公定法とバイ ダスを用いた 2 通りの検出法を比較検討した。 また， サ ルモネラの分離培地 SMID2 の実用性についても併せて 検討したところ次のような結果を得た。

1) 供試材料からのサルモネラの検出は, 合計 40 検 体中, 公定法で 7 件, バイダス ICS + plate 法で 3 件, バ イダス SLM; AFNOR 承認法で 10 件であった.

2) SE および ST をそれぞれ接種した合計 80 試験に おけるサルモネラの検出は公定法では 75 件 (93.8\%), バイダス ICS + plate 法は 77 件 (96.3\%), バイダス SLM; AFNOR 承認法は 79 件（98.8\%）であった.

3）バイダスを用いた 2 法の公定法との一致率は, 91.7〜92.5\% であった.

4) サルモネラの分離培地 SMID2 は DHL と比較し 検出率に著しい差は認められなかったが，サルモネラ集 落の色調が明瞭であり鑑別が容易で，かつ偽陽性も少な かった.

\section{文献}

1）大畑克彦，本田敬康，仁科徳啓：電気ビーズを用いたサ
ルモネラ検出法の評価. 日食微誌, 14(2), 97-100 (1997).

2) 中川 弘：食品衛生及び公衆衛生における微生物迅速検 出法の課題. 食品工業, 46(16), 22-31 (2003).

3) Kuang-Sheng, Y.: Comparison between VIDAS Automatic Enzyme-Linked Fluorescent Immunoassay and Culture Method for Salmonella Recovery from Pork Carcass Sponge Samples. J. Food Prot., 65, 1656-1659 (2002).

4) Michael, S. C. and Wendy, A. L.: Evaluation of VIDAS Immuno-Concentration Salmonella Assay Plus Selective Plate Method (Hektoen,Bismuth Sulfite, Salmonella Identification) for Detection of Salmonella in Selected Food. Collaborative Study. J. AOAC Int., 85, 576-592 (2002).

5) VIDAS SLM kit for the rapid detection of Salmonella. AFNOR VALIDATION CERTIFICATE.

6) Vernozy-Rozand, C.: Detection of Escherichia coli O157 in French food samples using an immunomagnetic separation method and the VIDAS ${ }^{\mathrm{TM}}$ E. coli O157. Lett. Appl. Microbiol., 25, 442-446 (1997).

7) Vernozy-Rozand, C.: Evaluation of the VIDAS Methodology for Detection of Escherichia coli 0157 in Food Samples. J. Food Prot., 61(7), 917-20 (1998).

8) Michael, T. M. and Norman, J. S. : Vidas Detection of Campylobacter spp. in Poultry Samples. bioMerieux Regional Customer Symposium (1996).

9) Dean, C. and Pacita, I.: Comparison of the TECRA and VIDAS immunoassay system for the detection of Staphylococcus Enterotoxins in Foods. Australian Government Analytical Laboratories (1999).

10) VIDAS LIS kit for the rapid detection of Listeria AFNOR VALIDATION CERTIFICATE.

11) Graves, L. M.: Identification of Listeria monocytogenes by the VIDAS-system. American Society of Microbiology Annual Meeting in New Orleans, LA (1996).

12）酒井史彦, 青山顕司, 篠澤映子, 山縣 尚, 丸山 務, 五 十君靜信, 柳平修一：ナチュラルチーズからの Listeria monocytogenes 検出における自動免疫蛍光測定装置の利 用. 日食微誌, 22(1), 17-23 (2005).

13) ISO6579-Microbiology of food and animal feeding stuffs-Horizontal method for the detection of Salmonella spp. (2002).

14) Sperber, W. H. and Delbel, R. H.: Accelerated Procedure for Salmonella detection in dried food and feeds involving only broth cultures and serological reactions. Appl. Microbiol., 17, 533-539 (1969).

15）吉敷ゆみこ，石崎直人，草野友子，金子誠二，宮崎奉之： ダイナビーズおよびヤトロンビーズを併用した食肉から のサルモネラ分離方法の検討. 日食微誌，17(3), 189$193(2000)$.

16) 楠 淳, 伊藤 武: ELISAkit「Locate」による食肉から のサルモネラ検出法. 日食微誌, 11(4), 223-236 (1995). 